\title{
MEMBANGUN MORALITAS DALAM HUBUNGAN ANAK DAN ORANG TUA
}

\author{
Oleh: \\ Joko Wahono* \\ Universitas Cokroaminoto Yogyakarta
}

\begin{abstract}
Abstrak
Sebagaimana kita ketahui, bahwa manusia lahir di dunia ini tidaklah dapat lepas dari keberadaan orang tua kita masing-masing. Ketika Allah telah membuat satu ketentuan bahwa Manusia dilahirkan adalah dijadikan sebagai khalifah Nya di muka bumi, maka terkandung konsekuensi bahwa manusia harus diperkembang-biakkan.Maka dalam hubungan kodrati ini akan timbul pula hubungan antara yang lahir dengan yang dilahirkan. Dalam hal ini disebut dengan anak dan orang tua. Dari hubungan antara keduanya ini akhirnya melekat pula hubungan hak dan kewajiban antara keduanya.

Berbakti kepada orang tua merupakan perbuatan yang mulia dan termasuk kewajiban seorang anak. Tanpa orang tua tak mungkin kita bisa hadir di dunia ini. Sejak di dalam kandungan seorang anak telah merepotkan orang tuanya. Begitu pula disaat kelahiran, ibunya telah mempertaruhkan myawanya demi kelahiran sang buah hati di dunia ini dengan selamat, bahkan ia lebih rela kehilangan nyawanya asalkan anaknya selamat.

Setelah lahir, seiring dengan masa pertumbuhannya, kedua orang tua memelihara dan merawat dengan segenap kasih sayangnya. Dengan senang hati kedua orang tua mengasuh dan menafkahi agar anaknya dapat tumbuh sehat sehingga dapat berkembang secara layak sebagaimana manusia yang lain. Waktu, tenaga, pikiran, nafkah hidup diprioritaskan untuk sang buah hati. Hal seperti itu mereka curahkan hingga anaknya benar-benar dewasa dan dapat hidup mandiri, berkarya dan selanjutnya mampu memenuhi kebutuhannya sebagai manusia dewasa. Untuk mengingatkan hubungan kodrati tersebut, maka perlu kiranya dibentuk keluarga yang sarat dengan moralitas.
\end{abstract}

Kata Kunci: Membangun Hubungan, Moralitas, Anak dan Orang Tua

\section{Pendahuluan}

Dalam menjalani kehidupannya di dunia ini, manusia memiliki konsekuensi kodrati dari Allah SWT Tuhan yang menciptakan dan mengatur kehidupan seluruh makhluknya di dunia. Adapun ketetapan manusia yang merupakan makhluk yang bersifat individu sekaligus sebagai makhluk sosial ini tentunya memiliki konsekuensi yang harus dipenuhi.

Salah satu konskuensi manusia sebagai makhluk sosial adalah keharusan berinteraksi dengan manusia yang lain. Interaksi manusia yang paling dekat dan paling awal adalah 
interaksinya dengan ibu, ayah dan saudara sebagai satu kesatuan keluarga. Dalam hal ini, interaksi dengan ibu menjadi sangat erat karena sejak dalam kandungan pun manusia telah berinteraksi dengan ibunya, apalagi setelah dilahirkan.dan hingga dewasa. Bagian interaksi dengan ibu memilkim porsi paling banyak. Setelah itu, interaksi dengan ayah menduduki porsi kedua. Ayahlah yang telah menafkahi keluarga dan bertanggung jawab atas kelangsungan biduk keluarga, karena ayahlah sang nahkoda yang mengendalikan arah dan lajunya bahtera rumah tangga. Inilah gambaran betapa besar tanggung jawab orangtua dalam memenuhi nafkah bagi keluarganya.

Bisa di bayangkan ketika seorang ibu mengawali tanggung jawab besar terhadap anaknya yakni dengan bertaruh nyawa melahirkan buah cintanya. Setelah perjuangan berat melahirkan anaknya dimuka bumi ini, tidak serta merta setelah itu menjadi ringan beban pekerjaannya, akan tetapi justru jauh lebih berat dari yang ia bayangkan, dimana seorang ibu harus menyusui, merawat bahkan melindungi dari segala sesuatu yang membahayakan buah hatinya.

Disisi yang lain, seorang ayah bertanggung jawab untuk memenuhi segala kebutuhan hidup bagi anggota keluarganya. Dia sanggup menghadang bahaya demi terpenuhinya kebutuhan hidup, dia sanggup bertahan dalam terik matahari demi menyelesaikan pekerjaannya, dia tak pernah mengeluh ketika harus kecapekan dalam melaksanakan tugasnya. Sungguh betapa besar jasa mereka untuk anaknya. Namun semua itu dijalani dengan ikhlas demi melaksanakan ketetapan sang maha pencipta.

Allah SWT berfirman :

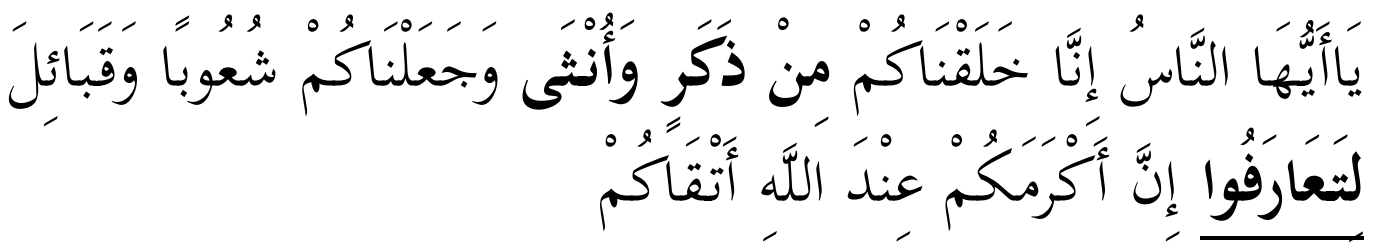

Artinya :"Hai manusia, sesungguhnya Kami menciptakan kamu dari laki-laki dan perempuan dan menjadikan kamu berbangsa-bangsa dan bersuku-suku agar kamu sekalian saling mengenal (ta'aruf). Sesungguhnya yang paling mulia di sisi Allah adalah orang yang paling takwa di antara kamu.” (QS. Al Hujurat 49:13).

Bertolak dari ayat di atas, sesungguhnya amatlah berat tugas dan tanggung jawab orang tua terhadap anak. Disamping keduanya harus memenuhi kebutuhan nafkah duniawi, mereka juga punya tanggung jawab spiritual, dimana dia harus mampu membentuk anaknya menjadi manusia yang bertaqwa kepada Allah SWT. Setelah kita tahu betapa besar tanggung jawab 
orangtua terhadap anaknya, tentunya disisi lain mereka mempunyai hak dari anak-anaknya. Hak itu adalah mendapatkan bakti dari anak-anak mereka.

Dengan dasar pemikiran di atas, maka bagi anak ada sebuah kewajiban untuk berbakti dengan sepenuh hati kepada orangtuanya. Segala bentuk hubungan dan baktinya kepada orangtua haruslah di jalani dengan segenap rasa keikhlasan dan penghormatan kepada kedua orangtua. Hubungan antara dua kepentingan ini haruslah tercipta dengan suasana yang nyaman dan penuh dengan moralitas yang memadai. Dengan kata lain kedua belah pihak harus memahami kedudukan masing-masing. Dengan memahami kedudukan masing-masing niscaya akan tercipta suasana yang kondusif dalam sebuah keluarga.

Diantara cara membentuk suasana yang kondusif dalam sebuah rumah tangga, terlebih soal hubungan antara orangtua dan anak hendaknya dibangun dengan sebuah komunikasi yang baik. Komunikasikan segala perasaan, kebutuhan maupun keinginan yang sekiranya harus dikomunikasikan untuk memperoleh solusi dari setiap persoalan yang ada. Hubungan ini bukan sekedar hubungan anak dan orangtua, akan tetapi merupakan hubungan moral yang harus dijaga dan dilestarikan agar tercipta sebuah kelauarga yang damai dan penuh cinta. Satu sama lain merupakan ikatan yang tak terpisahkan, ada ketergantungan yang erat karena hubungan ini menyangkut hak dan kewajiban pada masing-masing pihak.

Kewajiban orangtua yang sekaligus menjadi hak anak adalah Menafkahi dan mendidik. Nafkah lahir dan batin anak harus ditanggung oleh kedua orangtua. Dari segi pendidikan haruslah mencakup pendidikan tauhid/agama maupun ilmu pengetahuan umum. Kedua macam kewjiban di atas adalah menjadi hak bagi anak. Dimana anak boleh menuntut haknya sekalipun harus mempertimbangkan kemampuan orangtuanya.

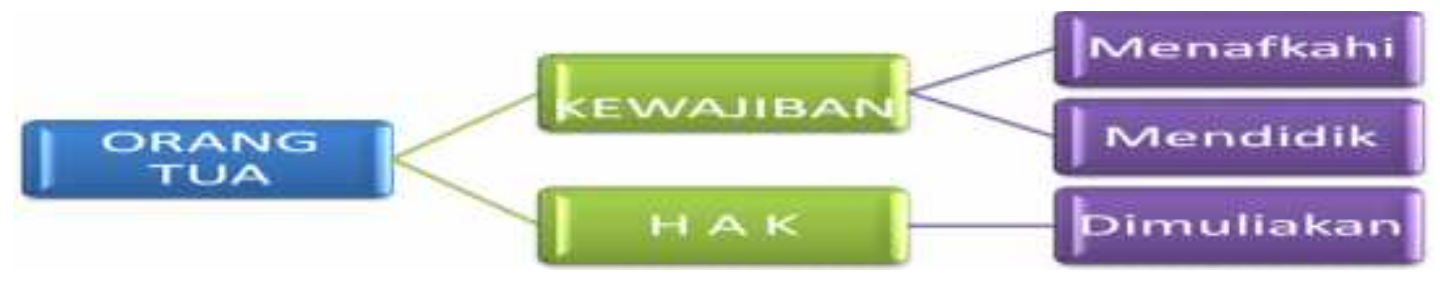

Dalam kehidupan dewasa ini, dimana tuntutan hidup dan perkembangan sosial sudah sedemikian maju, terkadang ada anak yang mengajukan tuntutan kepada orangtuanya melebihi kemampuan orangtua itu sendiri. Dengan alasan mengikuti perkembangan jaman, maka anak 
menuntut harus sama pula dengan kawannya dalam pergaulan sehari-hari. Berawal dari keprihatinan yang demikian ini, maka perlulah disadarkan akan pentingnya moralitas di dalam hubungan anak dan orang tua. Bagaimanakah anak harus bersikap pada orangtua dan sebaliknya bagaimana orangtua harus bersikap pada anaknya. Dengan sikap yang baik dan santun kiranya akan dapat tercipta suasana yang nyaman dan komunikasi yang baik dalam memenuhi kesenjangan kebutuhan antara anak dan orangtua.

Dengan memahami kedudukan, peran dan fungsi masing-masing kiranya akan terbentuklah sebuah kondisi yang tenang dan seimbang di dalam keluarga. Setiap gerak dan pekerjaan yang terjadi dalam keluarga itu merupakan satu sistem yang harmonis antara anak dan orangtua. Dalam hubungan horizantal merupaka hubungan hak dan kewajiban sebagai manusia, namun secara vertikal hubungan keduanya merupakan hubungan ibadah. Nafkah dan perhatian orangtua kepada anak merupakan aktualisasi dari kewajiban akan amanah dari Tuhan yang berupa anak. Sebaliknya Bakti anak-anak kepada orang tua adalah merupakan bentuk kewajiban dan penghargaan atas jerih payah orangtua kepadanya. Dua konsekuensi yang harmonis ini apabila bisa diwujudkan dalam keluarga merupakan nikmat yang tiada duanya bagi keluarga tersebut, dimana akhirnya Tuhanpun akan senang menyaksikan makhluknya yang mampu memenuhi kodratnya sebagai makhluk yang dimuliakan di muka bumi ini.

Berbakti kepada orangtua merupakan tindakan yang sangat disukai oleh Tuhan. Anak yang dapat berbakti kepada orangtua tentu akan mendapat kecintaan Tuhan serta kedudukan yang mulia di hadapan Nya. Dari Ibnu Mas'ud RA berkata:

Aku bertanya pada Rasulullah SAW : "Apakah amal yang paling utama ?" Beliau menjawab : "Shalat pada waktunya". Ku tanya : "Lalu apa lagi ?" Beliau menjawab : "Berbakti kepada orangtua”. Kutanya lagi : "Lalu apa lagi ?”. Beliau menjawab : “Jihad di jalan Allah”. (HR. Bukhari - Muslim). Dalam riwayat yang lain disebutkan,

Abdullah bin Umar berkata : "Suatu ketika ada orang laki-laki gagah lewat di depan kami, maka salah seorang di antara kami ada yang berkata : "Alangkah baiknya jika laki-laki itu pergi berjihad." Dan ketika itu Nabi SAW mendengar perkataan tersebut, lalu beliau bersabda : "Jika orangtua dari laki-laki itu masih hidup, dan dia mencari nafkah untuk mereka, maka itu lebih baik dari berjihad di jalan Allah. Dan jika ia mencari nafkah untuk mencukupi kebutuhan dirinya sendiri, maka itu juga lebih baik dari berjihad di jalan Allah.” 
Berdasarkan dari dua hadits di atas, dapa disimpulkan bahwa agama islam pun sangat mengapresiasi dan memberikan pemahaman kepada kita bahwa ketaatan dan kebaktian seorang anak kepada orangtua merupakan amal yang sangat tinggi kedudukannya di mata Tuhan. Oleh karena itu, amatlah penting hal ini kita tanamkan kepada anak agar ia memahami sebuah kewajiban yang harus ia kerjakan terhadap orangtuanya. Bukan saja dia mengutamakan haknya saja yang harus terpenuhi namaun ia juga akan menyeimbangkan diri dalam sikapnya sehari-hari, bahwa dibalik hak tentunya ada kewajiban pula yang harus ia penuhi. Di sisi yanglain, apabila kedua belah pihak telah menempatkan diri sesuai dengan kedudukannya, maka tentulah akan terdapat hikmah yang baik bagi keduanya.

\section{Buah Ketaatan Kepada Orang Tua}

Terbayang sudah buah ketaatan anak kepada orangtua, jika dari kacamata manusia saja akan mendapatkan kebaikan, tentunya dari sudut kacamata Tuhan akan di dapatkah hikmah kemuliaan bagi anak-anak yang mampu berbakti dengan sepenuh hati kepada kedua orangtua. Ibarat sebuah tanaman, tentu tanaman itu akan kita harap buahnya untuk kita. Diantara buah dari ketaatan anak kepada orangtua adalah :

1. Dicintai oleh Allah SWT.

Secara kodrati, orangtua dalam menafkahi anaknya adalah merupakan bentuk ketaatannya kepada Allah dengan merawat amanah berupa anak yang Allah titipkan kepadanya. Berarti orangtua telah mewakili Allah dalam melangsungkan perkembang biakan khalifah di muka bumi. Maka, jika ada anak yang mampu mencintai orangtua sebagaimana orangtua mencintai dirinya, dengan sendirinya anak yang demikian ini akan disayangi dan dicintai oleh Allah SWT.

2. Mulia dalam kehidupannya di dunia maupun di akhirat.

Dalam kehidupannya di dunia, anak yang dengan nyata berbakti kepada kedua orangtua secara tulus tentu akan mendapatkan kecintaan orangtua, saudara danmasyarakat di sekitarnya.Dia akan dimuliakan oleh manusia dalam kehidupannya di dunia. Di sisi yang lain Allahpun ridla akan amalnya itu sehingga Dia berkenan memberikan kemuliaan di akhirat dengan memberikan nikmat surgawi sebagai balasan amalnya menjunjung tinggi kedua orangtuanya. 
3. Akan di lebur dosa-dosa besarnya.

Ridla Allah tergantung dari ridla orangtua. Barangsiapa bisa meraih ridla dari kedua orangtua berarti Allahpun akan ridla kepadanya. Dengan keridlaan dari Allah inilah maka Dia berkenan akan menghapus dosa-dosa besarnya, bahkan diapun akan dijaga oleh Allah terhadap perbuatan-perbuatan yang mengakibatkan dosa itu sendiri.

4. Mendapat berkah dalam hidupnya.

Dengan mendapatkan ridla orangtua dan Allah sebagaimana di atas, maka Allah akan berkenan memberikan berkah dalam hidup anak yang berbakti kepada orangtua. Keberkahan itu merupakan sinergi doa orangtua yang ikhlas karena berkenan membalas bakti anak kepadanya dengan doanya tersebut. Maka ketentraman, kesehatan, dimudahkan urusan serta dicukupkan akan hajat-hajatnya adalah merupakan berkah yang besar dari Allah SWT.

5. Akan dilimpahkan rizkinya.

Sebagaimana kita ketahui bahwa rizkiitu tidaklah berwujud harta benda semata.

Selain itu kesehatan dan ketentraman hidup, mudahnya urusan dan penjagaan Allah dari segala mara bahaya adalah kekayaan non materiil yang tak terbilang nilainya dalan kehidupan. Dengan modal keadaan yang demikian itu, tentunya kelancaran dalam mengais rizkinya Allah akan mudah dilaksanakan. Dengan demikian maka akan lancar pula penghasilan dalam bentuk harta materiil. Dengan lancarnya penghasilan, maka akan diperoleh pula harta yang melimpah penuh berkah.

6. Akan di panjangkan umurnya.

Panjang umur di sini bukan panjang umur secara tekstual dengan banyaknya bilangan umur kita, akan tetapi lebih bermakna panjangnya berkah dan manfaat atas segala pemberian Allah sehingga hidup akan di penuhi dengan amal kebaikan bahkan hingga ia meninggalpun kemanfaatan itu masih bisa dirasakan oleh manusia lain sepeninggalnya. Inilah yang dimaksud dengan manusia yang dipanjangkan umurnya.

7. Sarana mendatangi telaga Nabi di surga nanti.

Barangsiapa berbakti kepada orangtua dengan bakti yang tulus, maka Allah berkenan mempertemukan dia dengan Nabi SAW di surga nanti. Bahkan Allah ijinkan anak yang demikian itu mendatangi telaganya Nabi di surga. 


\section{Melayani dan Mendoakan Orang Tua}

Melihat konteks hubungan antara anak dan orangtua, maka sudah selayaknyalah jika anak berkewajiban untuk melayani kedua orangtua baik ketika orang tua masih dalam keadaan mampu karena usia yang masih cukup muda, terlebih jika keadaan orangtua kita sudah dalam keadaan tua dan renta. Dulu ketika kita dalam keadaan masih tergantung pada orang dewasa, orangtua kitalah yang telah tulus merawat dan melindungi diri kita. Mereka berdua lebih mementingkan kebutuhan anaknya daripada kebutuhan mereka sendiri.

Sebagai anak yang berbakti, tentunya harus mengingat yang demikian ini. Kita harus bergantian memperhatikan kepentingan mereka terlebih jika kondisi orangtua kita telah payah dan renta. Penat dan renta dirinya karena di masa lalu sibuk dengan perjuangannya menafkahi kita. Sekarang giliran mereka telah lemah, tegakah hati kita menyakiti dan mngabaikan mereka?. Sebagai anak yang bermoralitas tinggi, tentu tidak akan sanggup menyaksikan penderitaan orangtuanya, terlebih ketika mereka telah renta dan tak mandiri lagi. Hati anak akan tersayat ketika melihat kenyataan bahwa dulu mereka tegar demi kita. Sekarang bisakah kita tegar demi mereka ?.

Pertanyaan seperti inilah yang harus kita jawab dengan bahasa moral, bukan logika semata. Ketika seorang anak mengingat betapa besar perjuangan dan pengorbanan mereka, tentu akan sangat memperhatikan kebutuhan beliau, melayani sepenuh hatinya sebagaimana dulu kita dilayani oleh mereka. Mereka ingin diperhatikan, dilayani, dicukupi dan disayangi oleh anakanak yang mereka dambakan dan banggakan. Orangtua selalu bangga ketika melihat anaknya menjadi orang yang sukses dan mapan kehidupannya. Lancar ekonominya, tentram keluarganya, sehat anak-anaknya. Ini merupakan dambaan setiap orangtua pada anak kesayangannya. Setiap orangtua tidak akan pernah tega melihat anaknya hidup sengsara. Di sinilah kita sebagai anak balik di uji oleh ALLAH, tegakah kita menyaksikan orang tuanya hidup menderita ? Jawabannya ada pada diri kita, sudah sejauh mana kebaktian kita kepada kedua orangtua, terlebih pada saat mereka berdua berusia tua dan kondisinya sudah renta.

Bentuk pengabdian seorang anak kepada orangtua yang paling sederhana adalah dengan mendoakan mereka agar mendapatkan ampunan dan kasih sayang Allah sebagaimana mereka menyayangi kita ketika kita masih kecil. 
“Allahummaghfirlii wa liwaalidayya warhamhuma kamaa rabbayaani saghiraa "(Ya Allah, ampunilah aku dan kedua orangtua ku, sayangilah mereka sebagaimana mereka menyayangi aku diwaktu diwaktu aku masih kecil).

Demikian bentuk kasih sayang kita kepada orangtua yang paling sederhana. Lalu sedapat mungkin kita perhatikan kebutuhan mereka. Jika mereka hidup bersama kita di usia senjanya, maka bertutur katalah dengan baik kepada mereka. Jangan kita buat mereka tersinggung dengan ucapan mereka. Bahagiakan mereka dengan memperhatikan apa-apa yang membuat mereka senang. Karena sesungguhnya tak ada satu orangtuapun yang mengharap semua jasanya di balas atau dikembalikan. Mereka hanya memberi tapi tak pernah mengharap kembali. Keikhlasan mereka mencurahkan semua pengorbanan kepada anaknya tiada tandingan dan bandingannya. Sebagai anak tak mungkin akan mampu membalas pengorbanan mereka. Maka dari itu jangan lah pernah berlaku sombong terhadap orang tua, terlebih kepada ibu. Ada satu hal yang tak penah bisa kita balas dengan apapun juga. Jika ibu pernah melahirkan anaknya, tapi seorang mustahil akan melahirkan ibunya. Inilah jasa seorang ibu yang taka akan pernah tertebus dengan apapun juga. Maka wajarlah jika Allah memberikan predikat seorang ibu adalah pemegang kunci surga bagi anak-anaknya. Dengan kata lain, jika ada anak berani durhaka pada ibunya, maka mustahil dia akan mendapatkan surganya di akhirat nanti.

\section{Memuliakan Orang Tua}

Agama islam memandang dan menempatkan kedudukan orangtua pada posisi yang sangat mulia. Maka sudah sepantasnyalah jika seorang anak wajib memuliakan keduanya sebagai bantuk ketaatan pada agama agar ketaatan tersebut memiliki kedudukan sebagai ibadah kepada Allah SWT. Berkat perjuangan ibu kita bisa lahir di dunia ini, berkat nafkah yang dicurahkan oleh ayah kita bisa bertahan hidup, dengan kasih sayang dan perawatannya kita bisa selamat dan akhirnya dapat hidup wajar sebagai manusia dewasa seperti sekarang ini.

Lelahnya mngurus dan merawat anaknya di waktu kecil, keikhlasannya dalam memberi penjagaan dan perlindungan kepada anaknya melebihi penjagaan terhadap dirinya sendiri. Bahkan ketika menyaksikan anaknya sakit, seorang ibu selalu akan berkata, Ya Allah lebih baik sakit yang Engkau timpakan kepada anakku Engkau pindahkan kepadaku saja, sungguh aku tidak tega menyaksikan penderitaan anakku. Demikian naluriah seorang ibu ketika mendampingi anaknya yang menderita karena menahan sakit. 
Demikian mulia akhlak dan jasa serta perjuangan mereka demi keselematan anak sebagai buah hatinya. Maka sebagai seorang anak, saat kita mendampingi orangtua kita diuji oleh Allah SWT mampukah kita menempatkan orangtua menjadi bagian dari hati kita ? Jawabannya adalah, hanya ada segelintir orang yangmemiliki kekhawatiran terhadap keadaan orangtuanya hingga benar-benar masuk sampai kedalam lubuk hatinya.

Maka Allah SWT telah perintahkan agar kita dapat berbuat baik dan memuliakan kedua orangtua melebihi kita memuliakan makhluk yang lain. Allah SWT berfirman di dalam QS Al Ahqaaf ayat 15 , yang artinya :

“ Dan Kami perintahkan kepada manusia untuk berbuat baik kepada kedua ibu bapak,ibunya mengandung dengan susah payah dan melahirkan dngan susah payah pula....”

Coba kita renungkan ayat di atas, dimana ayat itu menggambarkan betapa besar pengorbanan seorang ibu saat mengandung anaknya. Semakin bertambah usia kandungannya, maka bertambah berat pula penderitaannya. Belum lagi kita bayangkan peraaannya, kekhawatirannya akan keadaan anaknya kelak. Seorang ibu harus menata dan mempersiapkan persalinan yang semakin dekat. Pada saat hari kelahiran tiba, ibu memperjuangkan buah hatinya dengan mengenyampingkan keselamatan nyawanya sendiri. Dia tidak lagi mementingkan kehidupan dirinya, namun dia lebih mengutamakan pada kehidupan dan keselamatan bayinya.

Dalam ayat yang lain Allah juga berfirman, yang artinya :

“ Dan Kami perintahkan kepada manusia untuk berbuat baikmkepada kedua ibu bapaknya, ibunya telah mengandungnya dalam keadaan lemah yang bertambah-tambah dan menyapihnya dalam dua tahun.” (QS Lukmaan : 14)

Mengingat jasa ibu yang begitu besar, maka Allah pun akan memberikan penghargaan mulia bagi anak yang mampu berbakti kepada ibunya. Rasulullah SAW bersabda sebagai berikut

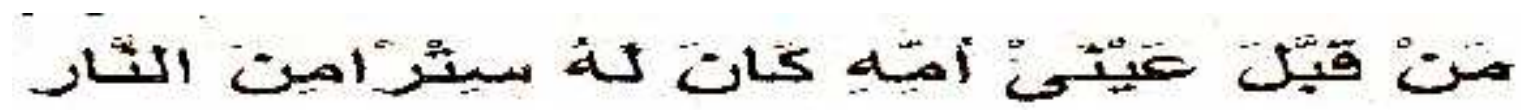

Artinya : Barangsiapa mencium kedua mata ibunya, maka hal itu akan menjadi tabir dari api neraka." 
Menurut penafsiran hadits di atas, jika ada anak yang mencium dan menjaga kedua mata ibunya dari mengeluarkan air mata maka akan di jauhkan dari api neraka. Dengan kata lain jika ada anak yang mampu berbuat baik kepada ibunya dengan membuat dia merasa mulia, bahagia dan bangga. Maka anak tersebut akan dilindungi Allah dari siksa neraka. Hal itu di karenakan anak tersebut telah berbakti dan tidak pernah menyakiti hati ibunya, sehingga Allahpun ridla terhadap anak tersebut dan Allah sendiri pula yang akan menyelamatkan dia dari siksa api neraka. Kebaktian anak dimaksud, tentunya adalah kebaktian yang mengikuti kaidah-kaidah baik berdasarkan moralitas pergaulan sehari-hari dalam kehidupan pada khalayak pada umumnya, terlebih moralitas yang berlandaskan pada al quran sebagai kitab Allah SWT.

\section{Mencari Rizki yang Halal demi Kelangsungan Hidup Keluarga}

Setelah merenungkan betapa berat perjuangan seorang ibu dalam andilnya melahirkan kita ke dunia, di sisi yang lain ada konsekuensi bagi seorang ayah. Dengan kelahiran anak sebagai buah hatinya, maka terbayang pula nafkah yang harus di tanggungnya demi sia anak. Dari nafkah paling dekat yakni beaya persalinan anaknya, perwatan ketika sakit, kebutuhan fasilitas kehidupan dan pendidikan, ayah jalani dengan penuh keikhlasan tanpa mengharap balasan dari si anak. Karena ayah berprinsip pada keyakina kepada Tuhan, dimana Allah SWT telah berfirman sebagai berikut :

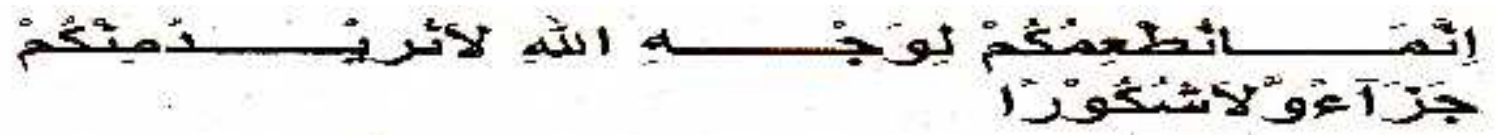

Artinya : Sesungguhnya kami memberi makan kepadamu hanya mengharap keridlaan Allah, kami tidak menharap balasan terima kasih dari kamu.” (QS Al Insaan : 9).

Dengan penuh keyakinan, seorang ayah mampu menerjang terik matahari, menantang resiko maut, tak peduli dengan segenap kepenatan hidup, semuanya di laksanakan dengan penuh keikhlasan demi memperoleh sesuap nasi dan beaya hidup untuk anak-anak dan keluarganya. Karena alasan di atas itulah maka seorang anak hendaknya berbakti dan memuliakan kedua orangtuanya yang telah merawat dan memperjuangkan kehidupan anaknya. Dengan demikian, berbakti dengan sepenuh hati dengan membangun moralitas yang tinggi menjadi satu kewajaran dan sekaligus kewajiban bagi seorang anak kepada kedua orangtuanya. Sebaliknya jika ada anak yang durhaka kepada kedua orangtua, maka sudah barang tentu Allah pun tak akan ridla 
kepadanya, sehingga bisa jadi mengantarkan anak tersebut pada kesengsaraan hidup di dunia dan siksa hidup di akhirat. Maka benarlah kiranya apa yang telah di sabdakan Nabi SAW bahwasannya Ridla Allah terhadap seorang anak itu bergantung pada keridlaan orangtuanya.

\section{Kesimpulan dan Hikmah}

Begitu besar penghargaan Allah SWT kepada orangtua yang telah rela Dia titipi amanh berupa anak sebagai khalifah penerus yang di harapkan membawa kebaikan dan kesejahteraan di masa datang. Seiring dengan kemuliaan yang di berikan Allah kepada orangtua, maka ada sebuah konsekuensi bagi anak, dimana anak mempunyai kewsjiban untuk berbakti kepada orangtua sebagai imbalan curahan pengorbanan orangtua kepada anak sejak anak lahir hingga anak dewasa dan mandiri.

Dalam hal ini ada kaidah yang telah di atur dalam agama islam sebagai bentuk pengabdian anak kepada orangtua. Kidah-kaidah tersebut antara lain :

1. Dalam hal berbakti kepada orangtua hendaknya lebih mengutamakan ibu, kamudia bapak.

2. Tidak boleh berkata kasar dan keras sehingga menyakiti hati kedua orangtua. Terlebih jika orangtua sudah dalam keadaan tua.

3. Menghormati kedua orangtua ketika masih hidup ataupun telah wafat.

4. Menjalin kasih sayang pada keduanya terlebih jika keduanya atau salah satunya masih hidup. Minimal dengan mendoakan kesehatan dan kesejahteraan mereka di hari tua serta memodhonkan ampunan.

5. Menjalin hubungan silaturaahmi, terlebih jika keduanya atau salah satunya masih hidup.

Hikmah yang akan kita peroleh dengan kita membangun moralitas dalam hubungan anak dan orangtua, maka kita akan memahami betapa besar pengorbanan mereka dikala kita masih kecil. Kasih sayang yang tercurah dari keduanya tak tergantikan, pengorbanan mereka tak terhitungkan, kemuliaan meraka tak tergeserkan. Maka jika ada anak yang mampu memuliakan kedua orangtua, maka Allahpun berkenan memuliakan anak tersebut. 


\section{Daftar Pustaka :}

Al Hikmah, Al Quran dan terjemahnya, Yayasan Penterjemah Al Quran, Disempurnakan Lajnah Pentashih Mushaf Al Quran, Diponegoro, Bandung, 2005.

Kumpulan Hadits Terpilih Shahih Bukhari, Ust,Maftuh Ahnan Asy, Terbit Terang, Surabaya, 2003.

Hukum Islam, Prof.H.Mohammad Daud Ali, SH, Raja Grafindo Persada, Jakarta, 1998, Edisi Revisi, 2014.

Ilmu Sosial Dasar, Ir.M.Munandar Soelaeman MS, PT. Eresco, Bandung, 1993.

Berita dari Surga dan Neraka, Terjemah Daqoiqul Akhbar, Karya Toha Putra, Semarang, 1992.

Ilmu Tauhid Tingkat Dasar, Achmad Sunarto, Al Miftah, Surabaya, 2012. 